\title{
Homologous expression of soluble methane monooxygenase genes in Methylosinus trichosporium OB3b
}

\author{
John S. Lloyd, Ruth Finch, Howard Dalton and J. Colin Murrell \\ Author for correspondence: J. Colin Murrell. Tel: +44 1203 523553. Fax : +44 1203523568 \\ e-mail:cm@dna.bio.warwick.ac.uk
}

Department of Biological Sciences, University of Warwick, Coventry CV4 7AL, UK

\begin{abstract}
An homologous expression system has been developed for soluble methane monooxygenase (sMMO) genes from Methylosinus trichosporium OB3b. SMMOminus mutants were previously obtained after marker-exchange mutagenesis, by the insertion of a kanamycin-resistance cassette into the mmoX gene of the SMMO operon. Complementation of the sMMO-minus genotype was achieved by conjugation with broad-host-range plasmids containing the native promoter and sMMO operon from Ms. trichosporium OB3b (pVK100SC and pHM2). In wild-type methanotrophs, copper ions present in the growth medium at concentrations greater than $0.25 \mu \mathrm{M}$ inhibit transcription of sMMO genes. The stable maintenance of pVK100Sc resulted in transconjugant methanotrophs with a decreased sensitivity to copper, since expression of sMMO occurred at copper sulphate concentrations of $7.5 \mu \mathrm{M}$. SMMO activity was only detected in soluble extracts after the addition of purified sMMO reductase component, which is inhibited by copper ions in vitro. This phenomenon could have arisen due to the increased number of sMMO gene copies (derived from pVK1005c) in the cell. Transconjugants obtained from conjugations with pHM2 expressed sMMO at copper concentrations of 0-2.5 $\mu \mathrm{M}$ only and sMMO activity was not restored by the addition of purified reductase component at copper concentrations higher than $2.5 \mu \mathrm{M}$. Southern hybridization showed that the plasmid had integrated into the chromosome, probably by a single homologous recombination event. This is the first report of homologous sMMO expression in a methanotroph with enzyme activities that are comparable to the activity reported in wild-type strains. This expression system will be useful for site-directed mutagenesis of active-site residues of SMMO from Ms. trichosporium OB3b.
\end{abstract}

Keywords: methanotroph, methane monooxygenase, recombinant, site-directed mutagenesis

\section{INTRODUCTION}

Methylosinus trichosporium OB3b is a methanotrophic bacterium which utilizes methane as a sole source of carbon and energy (Hanson \& Hanson, 1996). Methane is oxidized to methanol, which is then oxidized further to formaldehyde by methanol dehydrogenase. Formaldehyde is subsequently assimilated into biomass or further oxidized to $\mathrm{CO}_{2}$, providing reducing equivalents

Abbreviations: MMO, methane monooxygenase; sMMO, soluble methane monooxygenase; pMMO, particulate methane monooxygenase; NMS, nitrate mineral salts. for biosynthesis. Methane oxidation is catalysed by methane monooxygenase (MMO) (EC 1.14.13.25) in a reaction that requires oxygen and $\mathrm{NADH}$. Ms. trichosporium OB3b expresses two types of MMO : a membrane-bound, particulate MMO (pMMO) (Zahn \& DiSpirito, 1996; Nguyen et al., 1998) and a cytoplasmic, soluble MMO (sMMO) (Dalton et al., 1993; Lipscomb, 1994). The MMO enzymes of Ms. trichosporium OB3b are able to degrade important groundwater pollutants including trichloroethylene and other halogenated hydrocarbons (Oldenhuis \& Janssen, 1993). The highest rates of trichloroethylene degradation have been reported with $M$ s. trichosporium $\mathrm{OB} 3 \mathrm{~b}$ expressing sMMO (Oldenhuis et al., 1989; Brusseau et al., 1990). 
Expression of the two distinct types of MMO is dependent upon the availability of copper ions in the growth medium: a high copper-to-biomass ratio (>0.25 $\mu \mathrm{M}$ copper ions) results in pMMO expression and a low copper-to-biomass ratio $(<0.25 \mu \mathrm{M}$ copper ions) causes expression of sMMO (Stanley et al., 1983). Using Northern blotting and primer extension analysis, Nielsen et al. $(1996,1997)$ showed that sMMO-specific mRNAs were transcribed under conditions of low copper-to-biomass ratios. In the presence of copper, the level of sMMO-specific mRNAs decreased and pMMO transcripts were detected. Furthermore, copper ions inhibit activity of the reductase component in vitro in Methylococcus capsulatus (Bath) (Green et al., 1985) and Ms. trichosporium OB3b (Fitch et al., 1993).

sMMO has been purified and characterized from a number of methanotrophs, but most is known about the enzymes from Ms. trichosporium OB3b (Fox et al., 1989) and Mc. capsulatus (Bath) (Colby \& Dalton, 1978). Three protein components, the hydroxylase, the reductase and a regulatory protein $\mathrm{B}$, are required for activity of sMMO. The hydroxylase comprises three subunits, arranged in an $\alpha_{2} \beta_{2} \gamma_{2}$ configuration of about $250 \mathrm{kDa}$ (Woodland \& Dalton, 1989; Dalton et al., 1993). The $\alpha$ subunits contain a di-iron centre (Lipscomb, 1994) where methane and dioxygen interact to form methanol at the active site (George et al., 1996). The reductase is a single polypeptide and contains an FAD group and one $\mathrm{Fe}_{2} \mathrm{~S}_{2}$ centre per molecule. It accepts electrons from $\mathrm{NADH}_{2}$ and transfers them one at a time to the di-iron site of the hydroxylase (Lund et al., 1985). Protein B is a single-subunit protein containing no metals, prosthetic groups or cofactors (Green \& Dalton, 1985 ), the activity of which may be regulated by proteolysis (Lloyd et al., 1997).

The X-ray crystal structure of the hydroxylase from $M s$. trichosporium OB3b has been reported (Elango et al., 1997), demonstrating the high level of conservation within the active site of the hydroxylase from $M c$. capsulatus (Bath) (Rosenzweig et al., 1993). From these studies, active-site residues located within the $\alpha$ subunit (encoded by $m m o X$ ) of sMMO have been implicated as having key roles in the mechanism of methane oxidation, including Glu243, Thr213 and Cys151 (Rosenzweig et al., 1993, 1995, 1997). Site-directed mutagenesis experiments at these positions are important to understand how methane, a stable and relatively unreactive molecule, is hydroxylated.

The genes encoding sMMO from Ms. trichosporium OB 3 b have been cloned and sequenced (Cardy et al., $1991 \mathrm{a}, \mathrm{b})$. The $\alpha, \beta$ and $\gamma$ subunits of the hydroxylase are encoded by $m m o X, m m o Y$ and $m m o Z$, respectively, protein $B$ by $m m o B$ and the reductase by $m m o C$. $m m o B$ and mmoC from $M c$. capsulatus (Bath) were active when expressed in Escherichia coli, but the recombinant hydroxylase was inactive (West et al., 1992). sMMO from Ms. trichosporium $\mathrm{OB} 3 \mathrm{~b}$ was inactive when expressed in E. coli (Jahng et al., 1996). Active recombinant sMMO from Ms. trichosporium OB3b was reported in Pseudomonas putida F1, Agrobacterium tumefaciens and Rhizobium meliloti (Jahng \& Wood, 1994; Jahng et al., 1996). However, when the recombinant strains were assayed using the propylene oxidation assay (Pilkington \& Dalton, 1990; Fox et al., 1989), negligible sMMO activity was detected (Jahng et al., 1996).

Methanotrophs are difficult organisms to work with in terms of mutant isolation and gene transfer (Murrell, 1994). Marker-exchange mutagenesis has been used for the isolation of nitrogen-fixation mutants in methanotrophs (Toukdarian \& Lidstrom, 1984). A similar strategy was used to construct stable sMMO-minus mutants of Ms. trichosporium OB3b by the insertion of a $1.5 \mathrm{~kb}$ kanamycin-resistance gene into the chromosome (Martin \& Murrell, 1995). Six mutants were isolated that could not grow in the absence of copper, confirming an sMMO-minus pMMO-positive phenotype. Using a colorimetric assay based on the oxidation of naphthalene (Brusseau et al., 1990), sMMO activity was not detected and Southern hybridization confirmed the location of the kanamycin-resistance gene in the chromosome.

To overcome the lack of sMMO expression in an active form in heterologous hosts, the aim of this work was to complement the sMMO-minus genotype of Ms. trichosporium $\mathrm{OB} 3 \mathrm{~b}$ marker-exchange mutants with plasmidencoded sMMO genes. Complementation of the $m m o X-$ minus genotype with plasmid-encoded genes will allow active-site mutants to be expressed using this homologous expression system.

\section{METHODS}

Bacterial strains and growth conditions. The bacterial strains used in this study are described in Table 1 . Growth of methanotrophs was as described by Colby \& Dalton (1978) except that cultures were incubated at $30^{\circ} \mathrm{C}$. For the growth of cultures in minimal-copper, $0.1 \times$ nitrate mineral salts (NMS) was used, from which trace metal ions were removed using the methods described by Tsien et al. (1989). Cultures were grown in copper-plus media using $1 \times$ NMS from which trace metal ions were not removed. Ms. trichosporium $\mathrm{OB} 3 \mathrm{~b}$ was also grown in batch culture using a 2 litre fermenter under the following conditions : temperature, $30^{\circ} \mathrm{C}$; agitation speed, 500 r.p.m.; $\mathrm{pH}, 6 \cdot 8$, maintained via the automatic addition of $0.5 \mathrm{M} \mathrm{HCl}$ or $0.5 \mathrm{M} \mathrm{NaOH}$; methane supply, $60 \mathrm{ml} \mathrm{min}^{-1}$; air supply, $80 \mathrm{ml} \mathrm{min}^{-1}$. For continuous culture, the same conditions were used as for batch culture except that the culture was oxygen limited. The dilution rate was $0.02-$ $0.06 \mathrm{~h}^{-1}$ to maintain the $\mathrm{OD}_{540}$ at $2 \cdot 2-3 \cdot 8$. The switch from expression of sMMO to expression of pMMO was followed by the sequential addition of copper sulphate to $2 \cdot 5,5$ and $7.5 \mu \mathrm{M}$. Cells were harvested at steady state, which was reached after approximately $4-5$ volume changes $(6-8 \mathrm{~d})$.

Construction of plasmids. The plasmids used in this study (Table 1) were constructed in E. coli DH1 via methods described by Sambrook et al. (1989). pHM1 (Martin, 1994) was previously constructed by subcloning the streptomycinresistance gene $(\Omega)$ from pHP45 $\Omega$ (Prentki \& Krisch, 1984) as a Sall fragment and ligating it into pDSK509 (Keen et al., 1988) digested with the same enzyme. The sMMO operon from $M s$. trichosporium OB3b was excised from pMTL1000 (Martin, 1994) as a KpnI fragment and subcloned into KpnI-digested 
Table 1. Bacterial strains and plasmids

\begin{tabular}{|c|c|c|}
\hline Strain or plasmid & Description & Source or reference \\
\hline \multicolumn{3}{|l|}{ E. coli } \\
\hline DH1 & $\mathrm{F}^{-}$recA1 endA1 gyrA96 thi1 hsdR17 $\left(\mathrm{r}_{\mathrm{k}}{ }^{-} \mathrm{m}_{\mathrm{k}}{ }^{+}\right)$supE44 $\lambda^{-}$ & Low $(1968)$ \\
\hline S17-1 & RP4 2-Tetracycline: : Mu-Kanamycin:: Tn7 pro res $\bmod ^{+}$ & Simon et al. (1983) \\
\hline \multicolumn{3}{|l|}{ Methanotrophs } \\
\hline Ms. trichosporium $\mathrm{OB} 3 \mathrm{~b}$ & Type II possessing sMMO and pMMO & $\begin{array}{l}\text { University of Warwick } \\
\text { culture collection }\end{array}$ \\
\hline OB3b mutant $\mathrm{A}$ & $\begin{array}{l}\text { Kanamycin-resistant sMMO-minus single-crossover mutant of } \\
\text { OB3b }\end{array}$ & Martin \& Murrell (1995) \\
\hline OB3b mutant $F$ & $\begin{array}{l}\text { Kanamycin-resistant sMMO-minus double-crossover mutant of } \\
\text { OB3b }\end{array}$ & Martin \& Murrell (1995) \\
\hline RF100 & $\begin{array}{l}\text { Kanamycin- and tetracycline-resistant sMMO-minus single-crossover } \\
\text { mutant of OB3b harbouring pVK100 }\end{array}$ & This study \\
\hline RF100SC & $\begin{array}{l}\text { Kanamycin- and tetracycline-resistant sMMO-minus single-crossover } \\
\text { mutant of OB3b complemented with pVK100Sc }\end{array}$ & This study \\
\hline JLHM1 & $\begin{array}{l}\text { Kanamycin- and streptomycin-resistant sMMO-minus double- } \\
\text { crossover mutant of OB3b harbouring pHM1 }\end{array}$ & This study \\
\hline JLHM2 strains A-E & $\begin{array}{l}\text { Kanamycin- and streptomycin-resistant sMMO-minus double- } \\
\text { crossover mutant of OB3b complemented with pHM2 }\end{array}$ & This study \\
\hline \multicolumn{3}{|l|}{ Plasmids } \\
\hline pDSK509 & Kanamycin-resistant $\mathrm{Mob}^{+}$conjugative broad-host-range vector & Keen et al. (1988) \\
\hline 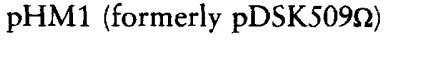 & $\begin{array}{l}\text { pDSK509 containing a streptomycin-resistance cassette as a BamHI } \\
\text { fragment }\end{array}$ & Martin (1994) \\
\hline pHM2 (formerly pDSK $509 \Omega S \mathrm{c}$ ) & $\begin{array}{l}\text { pHM1 containing the sMMO operon of Ms. trichosporium OB3b as } \\
\text { a KpnI fragment }\end{array}$ & Martin (1994) \\
\hline pDCV200 & $\begin{array}{l}\text { pBR325 containing a } 7.6 \mathrm{~kb} \text { HindIII fragment of } M s \text {. trichosporium } \\
\text { OB3b genomic DNA encoding } m m o X \text { and the } 5^{\prime} \text { region of mmoY }\end{array}$ & Cardy et al. (1991a) \\
\hline pDCV202 & $\begin{array}{l}\text { pBR } 325 \text { containing a } 2.6 \mathrm{~kb} \text { HindIII fragment of } M s \text {. trichosporium } \\
\text { OB3b genomic DNA encoding the } 3^{\prime} \text { region of } m m o Z \text {, orf } Y \text { and } \\
m m o C\end{array}$ & Cardy et al. (1991b) \\
\hline pMLT24 & Ampicillin-resistant pBR322-based cloning vector & Chambers et al. (1988) \\
\hline pMLT24-202 & $\begin{array}{l}\text { pMLT24 containing a HindIII fragment from pDVC200, encoding } \\
\text { the } 5^{\prime} \text { region of the Ms. trichosporium OB3b sMMO operon }\end{array}$ & Martin (1994) \\
\hline pMTL-1000 & $\begin{array}{l}\text { pMLT24 containing the sMMO operon subcloned from pDVC200 } \\
\text { and pDVC202 }\end{array}$ & Martin (1994) \\
\hline pVK100 & Kanamycin- and tetracycline-resistant IncP1, broad host range & Knauf \& Nester (1982) \\
\hline pVK100Sc & $\begin{array}{l}\text { pVK100 containing the Ms. trichosporium OB3b sMMO operon as } \\
\text { a BamHI fragment }\end{array}$ & Martin (1994) \\
\hline
\end{tabular}

pHM1, to generate pHM2 (Martin, 1994) (Fig. 1). pVK100Sc (Martin, 1994) was previously constructed by subcloning DNA encoding the $5^{\prime}$ region of the Ms. trichosporium OB3b sMMO operon from pDCV200 (Cardy et al., 1991a) as a HindIII fragment into pMLT24 (Chambers et al., 1988), to generate pMLT24-202 (Martin, 1994). The sMMO gene cluster from pDCV202 (Cardy et al., 1991b) was previously cloned into pMLT24-202 (Martin, 1994) to generate pMLT1000 containing the entire sMMO operon from Ms. trichosporium $\mathrm{OB} 3 \mathrm{~b}$. The complete sMMO operon was excised from pMTL1000 (using the multiple cloning sites in pMLT24) as a BamHI fragment. This was subcloned into pVK100 (Knauf \& Nester, 1982) linearized with BglII, generating pVK100Sc (Fig. 2). pHM2 and pVK100Sc both contain the native sMMO promoter sequence.

Isolation of plasmid DNA. Plasmid DNA was isolated from Ms. trichosporium OB3b using a method devised by Saunders \& Burke (1990) with the following modifications. A $50 \mathrm{ml}$ culture $\left(\mathrm{OD}_{540} 0 \cdot 5-0 \cdot 8\right)$ was pelleted and resuspended in $1.8 \mathrm{ml}$ solution 1 ( $50 \mathrm{mM}$ glucose, $20 \mathrm{mM}$ Tris/ $\mathrm{HCl}, 10 \mathrm{mM}$ EDTA, pH 8.0$)$ plus $200 \mu$ lysozyme $\left(10 \mathrm{mg} \mathrm{ml}^{-1}\right)$. The suspension was incubated at $37^{\circ} \mathrm{C}$ for $15 \mathrm{~min}$, followed by addition of $4 \mathrm{ml}$ solution $2(0.2 \mathrm{M} \mathrm{NaOH}, 1 \%, \mathrm{w} / \mathrm{v}, \mathrm{SDS})$ and incubation for $15 \mathrm{~min}$ on ice. Then $4 \mathrm{ml}$ solution 3 (3 $\mathrm{M}$ potassium acetate, $\mathrm{pH} 4.8$ ) was added and the mixture inverted every $2 \mathrm{~min}$ for $10 \mathrm{~min}$ (on ice).

Nick-translation and Southern hybridization. These methods were performed according to Sambrook et al. (1989). The following radiolabelled DNA fragments derived from pHM2 were used to probe JLMH2-C: the $1.7 \mathrm{~kb}$ PvulI kanamycinresistance cassette; the $2 \mathrm{~kb} \mathrm{BamHI}$ streptomycin-resistance cassette; and the $2 \mathrm{~kb}$ SacI-SalI fragment of $\operatorname{mmoX}$ (Fig. 1).

Conjugation. The technique used for conjugating plasmids from E. coli into methanotrophs was based upon a method developed by Martin (1994). Batch cultures of methanotrophs 
sMMO operon of Ms. trichosporium OB3b contained within pMTL1000

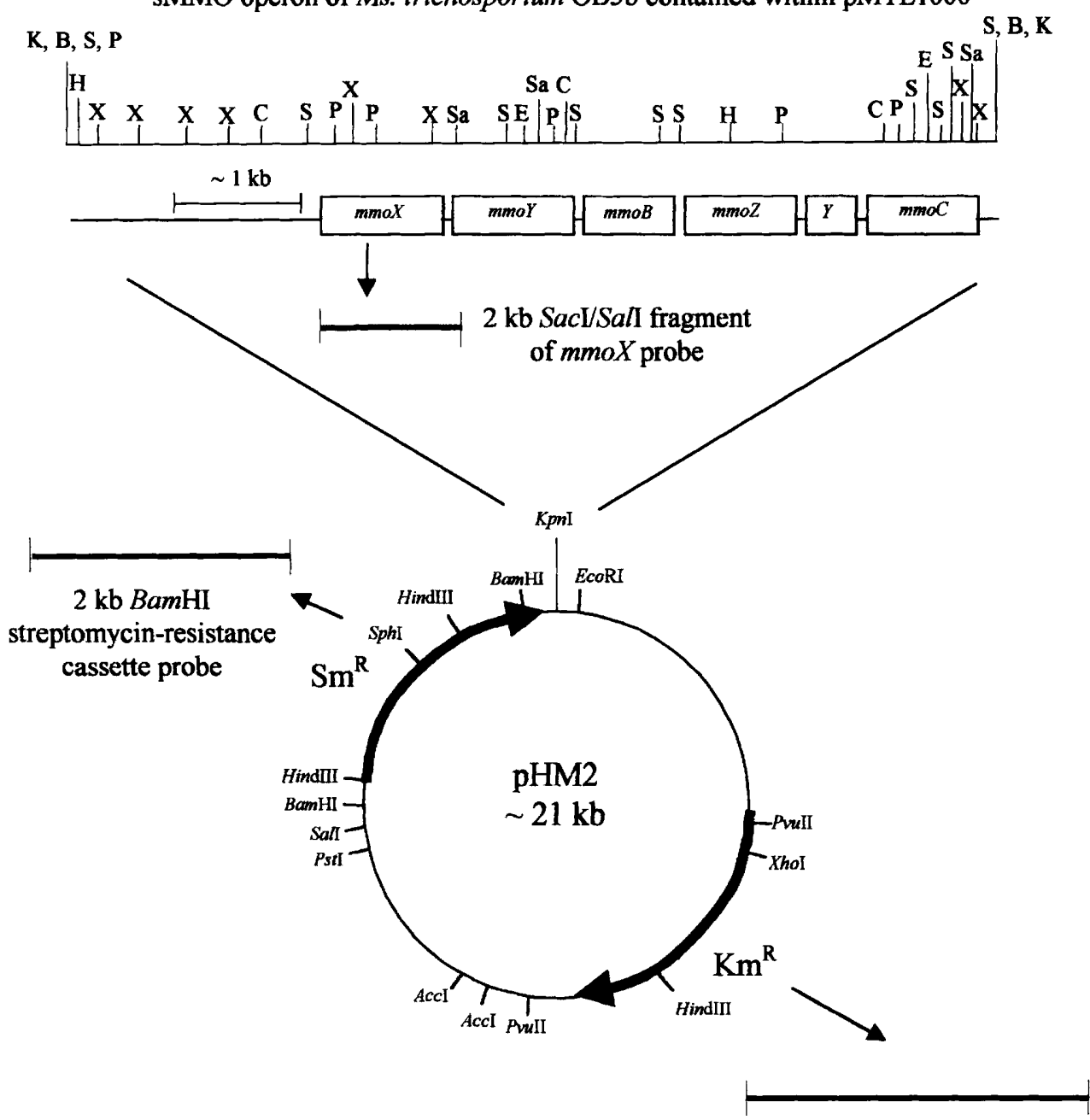

$1.7 \mathrm{~kb}$ Pvull kanamycin-resistance cassette probe

Fig. 1. Restriction map of $\mathrm{pHM} 2$ (Martin, 1994) containing the sMMO operon from Ms. trichosporium OB3b. $\mathrm{Km}^{R}$, kanamycin-resistance gene; SmR , streptomycin-resistance gene; B, BamHI; C, Clal; H, HindIII; K, Kpnl; P, Pstl; S, Sall; Sa, Sacl; $X, X$ hol. Probes used for Southern hybridizations are also shown.

at an $\mathrm{OD}_{540}$ of approximately 0.2 were used; $50 \mathrm{ml}$ of methanotroph recipient and $10 \mathrm{ml}$ of overnight donor $E$. coli S17-1 culture containing the plasmid to be conjugated were washed with NMS. They were collected on a $47 \mathrm{~mm}$ sterile nitrocellulose filter $(0 \cdot 2 \mu \mathrm{m}$ pore size). The filter was placed on NMS agar containing $0.02 \%(\mathrm{w} / \mathrm{v})$ Proteose Peptone and incubated for $24 \mathrm{~h}$ at $30^{\circ} \mathrm{C}$ in the presence of methane $\langle 50 \%$ in air). Cells from the conjugation plates were resuspended in $10 \mathrm{ml} \mathrm{NMS}$ and concentrated by centrifugation at $7000 \mathrm{~g}$ for 5 min. The cell pellet was resuspended in $1 \mathrm{ml} \mathrm{NMS}$ and $100 \mu \mathrm{l}$ aliquots plated onto selective agar, followed by incubation for 2-3 weeks with methane/air $(1: 1, v / v)$ until single colonies appeared.

Preparation of soluble and insoluble extracts. Methanotrophs were lysed by four passages through a French pressure cell at $137 \mathrm{MPa}$ and centrifuged at $50400 \mathrm{~g}$ for $60 \mathrm{~min}$ at $4{ }^{\circ} \mathrm{C}$. Soluble extracts (containing sMMO) were prepared as previously described (Fox et al., 1989). Insoluble extracts (con- taining pMMO) were prepared by resuspending the insoluble material in a minimum volume of $25 \mathrm{mM}$ MOPS, $\mathrm{pH} 7 \cdot 0$, containing $40 \mu \mathrm{M}$ copper sulphate.

Protein purification. Purifications of sMMO from $M c$. capsulatus (Bath) and Ms. trichosporium OB3b were undertaken as described by Colby \& Dalton (1978) and Fox et al. (1989), respectively.

Enzyme assay. sMMO activity in soluble and insoluble extracts was determined by the propylene oxidation assay of Pilkington \& Dalton (1990). The colorimetric naphthalene oxidation assay was used to detect sMMO activity in whole cells (Brusseau et al., 1990). Naphthalene oxidation plate assays for sMMO were performed as described by Bodrossy $e t$ al. (1995).

Determination of protein concentration. Protein concentration was assayed using Bradford protein assay reagent (BioRad) with bovine serum albumin as the standard. 


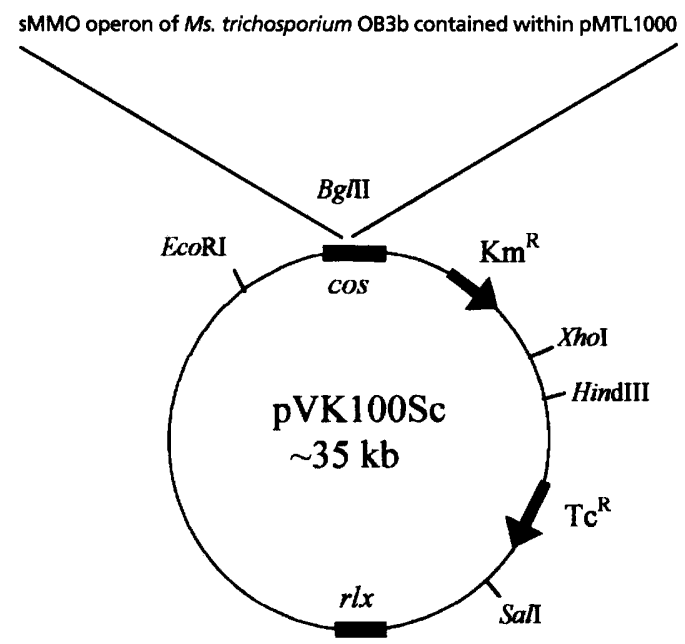

Fig. 2. Restriction map of pVK100Sc (Martin, 1994) containing the sMMO operon from Ms. trichosporium OB3b. $\mathrm{Y}$, orf $Y ; \mathrm{Km}^{\mathrm{R}}$, kanamycin resistance gene; $\mathrm{TC}^{\mathrm{R}}$, tetracycline resistance gene; $r / x$, conjugal transfer locus of RK2; $\cos$, $\cos$ site of phage $\lambda ; B$, BamHI; E, EcoRI; H, HindIII; P, Pstl; S, Sall; X, Xhol. See Fig. 1 for a detailed map of the sMMO operon.

Antibodies. Antiserum against the hydroxylase component of sMMO from Ms. trichosporium OB3b was raised as previously described (Woodland \& Dalton, 1989), except that the pure hydroxylase was denatured by heating for $5 \mathrm{~min}$ at $80^{\circ} \mathrm{C}$ before mixing with Freund's adjuvant.

SDSPAGE and Western blotting. SDS-PAGE was performed with an X-Cell II apparatus (Novex). Acrylamide gels $(12 \%$, w/v) (Laemmli, 1970) were stained with Coomassie brilliant blue. Molecular masses were calculated using Mark 12 widerange protein standards (Novex). Western blotting was performed with an X-Cell II Blot Module (Novex) and Hybond C nitrocellulose membranes (Amersham).

\section{RESULTS}

\section{Growth of Ms. trichosporium OB3b sMMO-minus mutants}

Ms. trichosporium OB3b mutants A and F were used in this study, which both have a kanamycin-resistance cassette inserted into mmoX (Martin \& Murrell, 1995). Mutant A arose from a single homologous recombination event, while mutant $F$ arose from a double homologous recombination event. Since naphthalene is oxidized by sMMO and not pMMO, the naphthalene oxidation assay was used to screen for the absence of sMMO activity in the sMMO-minus mutants. Three hundred single colonies of each mutant were subcultured onto minimal-copper and copper-plus agar both containing $50 \mu \mathrm{g}$ kanamycin $\mathrm{ml}^{-1}$. Wild-type Ms. trichosporium $\mathrm{OB} 3 \mathrm{~b}$ was used as the positive control. After 3 weeks growth, naphthalene oxidation plate assays confirmed that sMMO activity was absent in the $M s$. trichosporium $\mathrm{OB} 3 \mathrm{~b}$ sMMO-minus mutants grown on copper-plus or minimal-copper agar. Wild-type Ms. trichosporium $\mathrm{OB} 3 \mathrm{~b}$ gave a positive naphthalene oxidation assay result on minimal-copper agar only. Using minimal-copper $0.1 \times$ NMS batch cultures, sMMO expression was detected in the wild-type organism only. Although sMMO expression was not detected in the Ms. trichosporium OB3b sMMO-minus mutants under the same conditions, growth was evident, possibly due to scavenging of trace amounts of copper (necessary for the expression and activity of pMMO) from the medium by these cells. Western blotting with antiserum against the hydroxylase of Ms. trichosporium OB3b confirmed that the $\alpha, \beta$ and $\gamma$ subunits of the hydroxylase were expressed. Western blot analysis of soluble extracts from Ms. trichosporium OB3b mutant $\mathrm{F}$ demonstrated cross-reactivity with the $\beta$ and $\gamma$ subunits of the hydroxylase, which are probably still expressed since there is not a transcriptional terminator within the kanamycin-resistance cassette inserted into $\mathrm{mmoX}$ (Fig. 3a). Therefore, in Ms. trichosporium OB3b mutant $\mathrm{F}$ at least, sMMO expression could be restored by complementation of $m m o X$ only.

\section{Conjugation of broad-host-range plasmids into Ms. trichosporium OB3b sMMO-minus mutants}

To select for Ms. trichosporium OB3b mutant A transconjugants harbouring pVK100 and pVK100Sc, $50 \mu \mathrm{g}$ kanamycin ml${ }^{-1}$ and $20 \mu \mathrm{g}$ tetracycline $\mathrm{ml}^{-1}$ were used. Ms. trichosporium OB3b mutant A [pVK100] transconjugants (designated RF100) were isolated at a frequency of $2 \times 10^{-8}$ per recipient. Ms. trichosporium OB3b mutant A [pVK100Sc] transconjugants (designated RF100SC) were isolated at a frequency of $1 \times 10^{-8}$ per recipient. To select for Ms. trichosporium OB3b mutant $\mathrm{F}$ transconjugants harbouring $\mathrm{pHM} 1$ and pHM2, $50 \mu \mathrm{g}$ kanamycin $\mathrm{ml}^{-1}$ and $25 \mu \mathrm{g}$ streptomycin $\mathrm{ml}^{-1}$ were used. Ms. trichosporium OB3b mutant $\mathrm{F}$ [pHM1] transconjugants (designated JLHM1) were selected on copper-plus agar at a frequency of $1.7 \times 10^{-7}$ per recipient. Ms. trichosporium OB3b mutant $\mathrm{F}$ [pHM2] transconjugants (designated JLHM2) were selected on copper-plus agar at a frequency of $1.2 \times 10^{-7}$ per recipient. Spontaneous resistance to kanamycin and tetracycline and/or kanamycin and streptomycin was observed at frequencies of $<1 \times 10^{-10}$ in the sMMOminus mutants.

\section{Identification of SMMO-positive transconjugant methanotrophs}

The putative transconjugant methanotrophs isolated above were replica-plated onto copper-plus and minimal-copper agar. After growth for 3 weeks in the presence of methane, the naphthalene oxidation plate assay was used to screen for the sMMO activity. No sMMO-positive JLHM1 or RF100 transconjugants were isolated, despite repeated attempts. sMMO activity was identified in RF100SC, and the activity continued to be maintained on minimal-copper agar containing $50 \mu \mathrm{g}$ kanamycin $\mathrm{ml}^{-1}$ and $20 \mu \mathrm{g}$ tetracycline $\mathrm{ml}^{-1}$. Three sMMO-positive JLHM2 transconjugants, designated JLHM2-A, JLHM2-B and JLHM2-C, were identified on minimal-copper agar. Replica-plating all of the trans- 
(a)

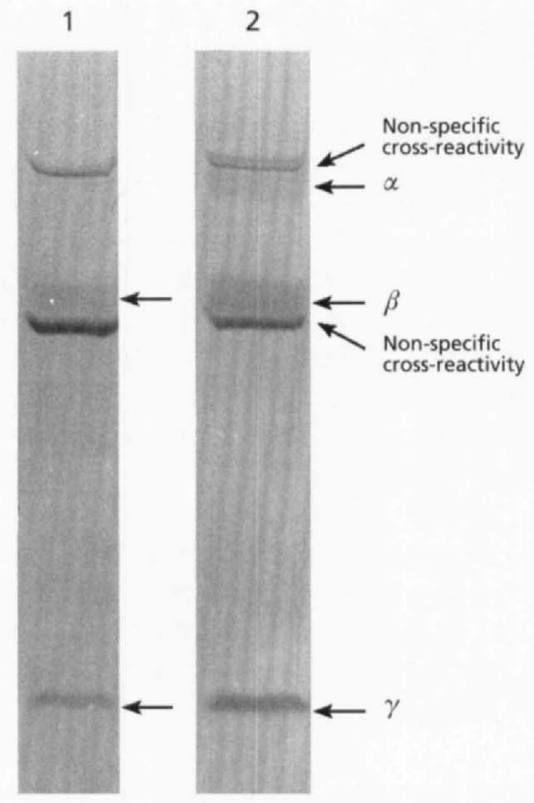

(b)

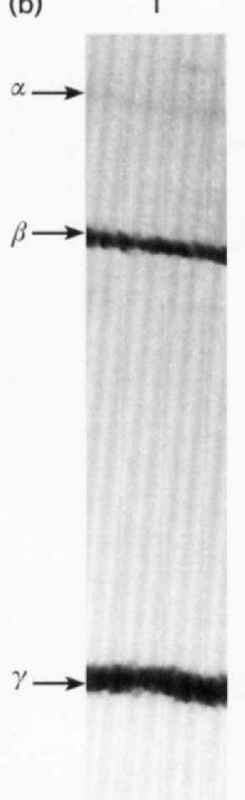

2

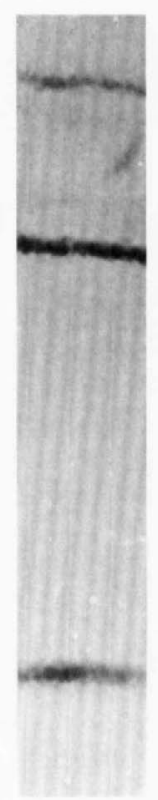

3

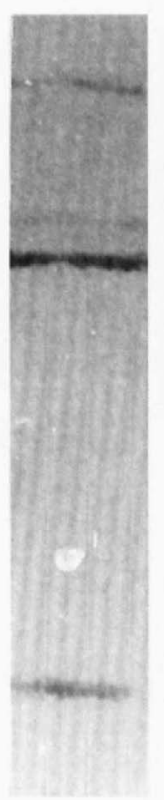

4

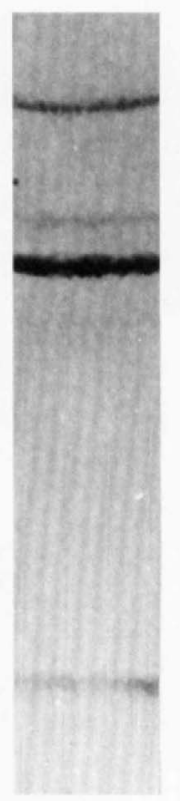

5

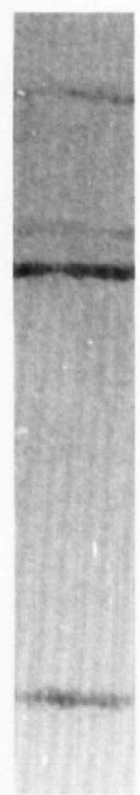

Fig. 3. (a) Extracts of Ms. trichosporium OB3b mutant F (lane 1) and wild-type Ms. trichosporium OB3b (lane 2), both grown in minimal-copper $0.1 \times$ NMS batch culture, Western blotted and probed with antiserum against the hydroxylase of Ms. trichosporium OB3b. Each lane contained $40 \mu \mathrm{g}$ soluble extract. (b) Extracts of RF100sC probed with antiserum against the hydroxylase from Ms. trichosporium OB3b. Lane 1, $5 \mu \mathrm{g}$ purified hydroxylase from Ms. trichosporium OB3b; lanes $2,3,4$ and $5,30 \mu \mathrm{g}$ soluble extract of RF100SC grown with $0,2.5,5$ and $7.5 \mu \mathrm{M}$ copper sulphate, respectively. At $0 \mu \mathrm{M}$ copper, the medium would contain a minimal amount of contaminating copper.

conjugants harbouring pHM2 onto minimal-copper agar for a second time, followed by naphthalene oxidation plate assays, identified two more sMMOpositive transconjugants, designated JLMH2-D and JLHM2-E. These five sMMO-minus mutants that had been complemented with pHM2 were maintained on minimal-copper agar containing $50 \mu \mathrm{g}$ kanamycin $\mathrm{ml}^{-1}$ and $25 \mu \mathrm{g}$ streptomycin $\mathrm{ml}^{-1}$.

\section{Growth of RF100SC and JLHM2-C in batch and continuous culture}

RF100SC and JLHM2-C were each grown in a 2 litre fermenter containing $1 \times$ NMS with $1 \mu \mathrm{M}$ copper sulphate. This medium was used to ensure that the transconjugant methanotrophs could grow using pMMO, prior to the depletion of copper and expression of sMMO. This occurred as the cell density rose above an $\mathrm{OD}_{540}$ of 2 and a biomass concentration of $0.86 \mathrm{~g}$ dry cell weight $1^{-1}$ (assuming a dry cell weight of $0.429 \mathrm{~g} \mathrm{l}^{-1}$ at an $\mathrm{OD}_{540}$ of 1.0: Pilkington, 1986). The positive control used in all cases was wild-type Ms. trichosporium $\mathrm{OB} 3 \mathrm{~b}$. When cells were expressing pMMO, the growth rate of Ms. trichosporium OB3b was $0.05 \mathrm{~h}^{-1}$ and during expression of sMMO, the growth rate was $0.052 \mathrm{~h}^{-1}$. The corresponding growth rate of RF100SC was approximately $0.05 \mathrm{~h}^{-1}$ when expressing either pMMO or sMMO. The growth rate of JLHM2-C was $0.024 \mathrm{~h}^{-1}$ when cells were expressing pMMO; it was $0.034 \mathrm{~h}^{-1}$ during expression of sMMO. The switch from expression of $\mathrm{pMMO}$ to expression of sMMO occurred at a biomass concentration of $0 \cdot 8-1 \cdot 1 \mathrm{~g}$ dry cell weight $1^{-1}$, in all cases.

\section{Expression and activity of SMMO in RF100SC and JLHM2-C}

Continuous culture was used to determine the enzyme activity of MMO in the different methanotroph mutants complemented with sMMO genes. This also allowed the switch from expression of sMMO to pMMO to be monitored by the addition of increasing concentrations of copper sulphate. Propylene oxidation assays of soluble and insoluble extracts were performed at increasing copper sulphate concentrations, to determine the location and activity of MMO (Table 2). Specific activities of MMO from wild-type Ms. trichosporium OB3b grown in NMS containing between 0 and $1 \mu \mathrm{M}$ copper sulphate in continuous culture have been reported in the range of $20-80 \mathrm{nmol}$ propylene oxidized $\min ^{-1}$ (mg protein) ${ }^{-1}$ for the soluble fraction (containing sMMO) and 0-8 nmol propylene oxidized $\min ^{-1}$ (mg protein) $)^{-1}$ for the insoluble fraction (containing $\mathrm{pMMO}$ ) (Burrows et al., 1984; Park et al., 1991; Fox et al., 1991; Martin, 1994). The MMO activities detected during this work in soluble extracts of wild-type Ms. trichosporium OB3b and RF100SC were comparable to values given in these reports. Specific activities of MMO of $140 \pm$ $13 \mathrm{nmol}$ propylene oxidized $\mathrm{min}^{-1}$ (mg protein) ${ }^{-1}$ were obtained for the soluble fraction of JLHM2-C. Such high activities had only previously been observed in wild-type Ms. trichosporium OB3b by Stirling \& Dalton 
Table 2. Enzyme activities during a switch from expression of $S M M O$ to the expression of pMMO in wild-type and transconjugant methanotrophs

Soluble, 1 to $5 \mathrm{mg}$ soluble extract; insoluble, $1 \mathrm{mg}$ insoluble extract. sMMO activity resides in the soluble fraction and pMMO activity in the insoluble fraction. In vitro activity of pMMO is likely to be lower than in vivo pMMO activity. The results are means of triplicate assays \pm SD. ND, Not detected.

\begin{tabular}{|c|c|c|c|}
\hline \multirow[t]{2}{*}{ Strain } & \multirow{2}{*}{$\begin{array}{c}\text { Copper } \\
\text { sulphate } \\
\text { concn }(\mu \mathrm{M})\end{array}$} & \multicolumn{2}{|c|}{$\begin{array}{l}\text { Propylene oxidation activity }\left[\mathrm{nmol} \mathrm{min}^{-1}\right. \\
\left.\qquad(\mathrm{mg} \text { protein })^{-1}\right]\end{array}$} \\
\hline & & Soluble extract & Insoluble extract \\
\hline Wild-type OB3b & $\begin{array}{l}0 \\
2 \cdot 5 \\
5 \\
7 \cdot 5\end{array}$ & $\begin{array}{c}42 \pm 9 \\
10 \pm 4 \\
\text { ND } \\
\text { ND }\end{array}$ & $\begin{array}{c}3 \pm 1 \\
18 \pm 10 \\
57 \pm 8 \\
63 \pm 12\end{array}$ \\
\hline JLHM2-C & $\begin{array}{l}0 \\
2 \cdot 5 \\
5 \\
7 \cdot 5\end{array}$ & $\begin{array}{c}140 \pm 13 \\
29 \pm 3 \\
4 \pm 0.5 \\
\text { ND }\end{array}$ & $\begin{array}{c}\text { ND } \\
21 \pm 4 \\
49 \pm 9 \\
74 \pm 15\end{array}$ \\
\hline RF100SC & $\begin{array}{l}0 \\
2 \cdot 5 \\
5 \\
7 \cdot 5\end{array}$ & $\begin{array}{c}54 \pm 0 \cdot 6 \\
12 \pm 0 \cdot 2 \\
3 \pm 0 \cdot 4 \\
50 \pm 0 \cdot 9\end{array}$ & $\begin{array}{c}\text { ND } \\
62 \pm 0 \cdot 3 \\
65 \pm 0 \cdot 2 \\
66 \pm 0 \cdot 4\end{array}$ \\
\hline
\end{tabular}

*Activity was detected in the soluble fraction by the addition of saturating amounts of purified reductase from Mc. capsulatus (Bath).

(1979), who observed very high MMO activity in the soluble fraction: $84-146 \mathrm{nmol}$ propylene oxidized $\mathrm{min}^{-1}$ $(\mathrm{mg} \text { protein })^{-1}$. Propylene oxidation activity was not detected in soluble extracts of RF100 or JLHM1.

The soluble and insoluble extracts that were assayed for MMO activity were also analysed by SDS-PAGE and Western blotting using antiserum against the hydroxylase component of Ms. trichosporium $\mathrm{OB} 3 \mathrm{~b}$ as probe. In wild-type Ms. trichosporium OB3b and JLHM2-C grown in continuous culture, the hydroxylase of sMMO was detected in the soluble fraction of cells grown in the absence of copper only. At 2.5 and $5 \mu \mathrm{M}$ copper sulphate, it was possible that the enzyme activity detected in the soluble extracts of JLHM2-C (Table 2) was derived from sMMO polypeptides present at a concentration too low to be detected by Western blotting. Constitutive expression of the hydroxylase was observed in RF100SC, grown in continuous culture at unusually high copper sulphate concentrations of $7 \cdot 5 \mu \mathrm{M}$, as determined by Western blotting (Fig. 3b). At a copper sulphate concentration of $7.5 \mu \mathrm{M}$, sMMO activity could be detected in soluble extracts only by the addition of saturating amounts of purified sMMO reductase from $M c$ c capsulatus (Bath). Purified sMMO reductase from Ms. trichosporium OB3b was not available. The restoration of sMMO activity in vitro suggested that the lack of sMMO activity in whole cells grown in medium with copper sulphate added to $7.5 \mu \mathrm{M}$ was due to the inactivation of the reductase component. Inactivation of the reductase from Mc. capsulatus (Bath) by copper has previously been demonstrated by Green $e t$ al. (1985). This result also confirmed functional complementation between the reductase of Mc. capsulatus (Bath) and the other sMMO components of Ms. trichosporium OB3b as previously reported (Stirling \& Dalton, 1979).

\section{Analysis of plasmid and chromosomal DNA from RF100SC and JLHM2-C}

Southern blot analysis was used to elucidate how complementation of the sMMO-minus genotype in $M s$. trichosporium OB3b mutants $\mathrm{A}$ and $\mathrm{F}$ had occurred. Using the modified alkaline lysis method developed in this work, attempts were made to isolate plasmid DNA from Ms. trichosporium OB3b, RF100, RF100SC, JLHM1 and JLHM2-C. Plasmid DNA was successfully isolated from all the methanotrophs except JLHM2-C. Southern blotting of the plasmid DNA isolated from RF100 and RF100SC confirmed that the DNA isolated was pVK100 and pVK100Sc, respectively, and that no significant deletions or modifications to these plasmids had occurred. It therefore appeared that sMMO expression had been restored in Ms. trichosporium OB3b mutant A via transcription of sMMO genes carried by pVK100Sc. Since repeated attempts to isolate plasmid DNA from JLHM2-C were unsuccessful, restriction digests of chromosomal DNA were performed and used in Southern hybridizations. Positive hybridization was identified with kanamycin- and streptomycin-resistance gene probes and a $m m o X$ probe (see Methods). Analysis of the hybridization fragments obtained suggested that, 
require a higher concentration of copper for the repressor to bind and cause a net repression. At copper sulphate concentrations of $7.5 \mu \mathrm{M}$, sMMO activity could only be detected in RF100SC by the addition of purified reductase from $M c$. capsulatus (Bath) to soluble extracts. This suggests that sMMO activity was lost due to inactivation of the reductase component by the higher concentration of copper as previously shown for the same component of the $M c$. capsulatus (Bath) enzyme (Green et al., 1985). Presumably RF100SC was able to utilize methane as a sole carbon and energy source when sMMO was inactive by co-expressing pMMO. Fitch et al. (1993) reported that sMMO activity in soluble extracts of wild-type Ms. trichosporium OB3b decreased by $25 \%$ in the presence of $15 \mu \mathrm{M}$ copper and that complete inactivation occurred with $75 \mu \mathrm{M}$ copper. Inactivation of sMMO activity by copper has also been studied in Mc. capsulatus (Bath) (Green et al., 1985). Copper ions at $10 \mu \mathrm{M}$ caused a $27 \%$ reduction in wholecell sMMO activity whilst $80 \mu \mathrm{M}$ copper ions caused complete inactivation of purified sMMO proteins.

Using this homologous system for the expression of hydroxylase mutants requires that transconjugants are grown under conditions of low copper-to-biomass ratios so that sMMO is expressed. If some of the mutations rendered the sMMO inactive, then the organism would not grow in conditions of low copper-to-biomass ratios and the mutated hydroxylase proteins would not be expressed. However, results obtained in this study suggest that when sMMO-minus mutants containing a kanamycin-resistance cassette in $m m o X$ are cultured in minimal-copper medium, the inactivated sMMO operon is still transcribed. The most likely explanation for this is that the organism scavenges sufficient copper for the concomitant expression of active pMMO and inactive sMMO, to utilize methane as a sole carbon and energy source. This result suggests that previous ideas about the lack of expression of pMMO in cells expressing sMMO are incorrect. Consequently, the hydroxylase which may be inactivated by mutations introduced into $m m o X$ by site-directed mutagenesis would still be expressed under growth conditions of minimal copper.

\section{ACKNOWLEDGEMENTS}

This work was supported through Biotechnology and Biological Sciences Research Council (BBSRC) studentships to John Lloyd and Ruth Finch. We thank Howard Martin for constructing some of the plasmids used in this work, as well as Robert Titmus and Susan Slade for excellent technical assistance. We also thank the reviewers for their helpful comments.

\section{REFERENCES}

Bodrossy, L., Murrell, J. C., Dalton, H., Kalman, M., Puskas, L. G. \& Kovacs, K. L. (1995). Heat-tolerant methanotrophic bacteria from the hot water effluent of a natural gas field. Appl Environ Microbiol 61, 3549-3555.

Brusseau, G. A., Tsien, H.-C, Hanson, R. S. \& Wackett, L. P. (1990). Optimisation of trichloroethylene oxidation by methanotrophs and the use of a colorimetric assay to detect soluble methane monooxygenase activity. Biodegradation 1, 19-29.

Burrows, K. J., Cornish, A., Scott, D. \& Higgins, I. J. (1984). Substrate specificities of the soluble and particulate methane monooxygenase of Metbylosinus trichosporium OB3b. J Gen Microbiol 130, 3327-3333.

Cardy, D. L. N., Laidler, V., Salmond, G. P. C. \& Murrell, J. C. (1991a). Molecular analysis of the methane monooxygenase (MMO) gene cluster of Metbylosinus trichosporium OB3b. Mol Microbiol 5, 335-342.

Cardy, D. L. N., Laidler, V., Salmond, G. P. C. \& Murrell, J. C. (1991b). The methane monooxygenase (MMO) gene cluster of Methylosinus trichosporium OB3b: cloning and sequencing of the $m m o C$ gene. Arch Microbiol 156, 477-483.

Chambers, S. P., Prior, S. E., Barstow, D. A. \& Minton, N. P. (1988). The pMTL nic ${ }^{-}$cloning vectors. I. Improved pUC polylinker regions to facilitate the use of sonicated DNA for nucleotide sequencing. Gene 68, 139-149.

Colby, J. \& Dalton, H. (1978). Resolution of the methane monooxygenase of Methylococcus capsulatus (Bath) into three components. Biochem J 171, 461-468.

Dalton, H., Wilkins, P. \& Jiang, Y. (1993). Structure and mechanism of action of the hydroxylase of soluble methane monooxygenase. In Microbial Growth on $\mathrm{C}_{1}$ Compounds, pp. 65-80. Edited by J. C. Murrell \& D. P. Kelly. Andover: Intercept Press.

Elango, N., Radhakrishnan, R., Froland, W. A., Wallar, B. J., Earhart, C. A., Lipscomb, J. D. \& Ohlendorf, D. H. (1997). Crystal structure of the hydroxylase component of methane monooxygenase from Methylosinus trichosporium OB3b. Protein Sci 6, $556-568$.

Fitch, M. W., Graham, D. W., Arnold, R. G., Agarwal, S. K., Phelps, P., Speitel, G. E., Jr \& Georgiou, G. (1993). Phenotypic characterisation of copper-resistant mutants of Methylosinus trichosporium OB3b. Appl Environ Microbiol 59, 2771-2776.

Fox, B. G., Froland, W. A., Dege, J. E. \& Lipscomb, J. D. (1989). Methane monooxygenase from Methylosinus trichosporium OB3b. Purification and properties of a three component system with high specific activity from a type II methanotroph. J Biol Chem 264, 10023-10033.

Fox, B. G., Liu, Y., Dege, J. E. \& Lipscomb, J. D. (1991). Complex formation between the protein components of methane monooxygenase from Methylosinus trichosporium OB3b. J Biol Chem 266, 540-550.

George, A. R., Wilkins, P. C. \& Dalton, H. (1996). A computational investigation of the possible substrate binding sites in the hydroxylase of soluble methane monooxygenase. J Mol Catal 2, 103-113.

Green, J. \& Dalton, H. (1985). Protein B of the soluble methane monooxygenase from Methylococcus capsulatus (Bath): a novel regulatory protein of enzyme activity. $J$ Biol Chem 260, 15795-15801.

Green, J., Prior, S. D. \& Dalton, H. (1985). Copper ions as inhibitors of protein $\mathrm{C}$ of soluble methane monooxygenase of Methylococcus capsulatus (Bath). Eur J Biochem 153, 137-144.

Hanson, R. S. \& Hanson, T. E. (1996). Methanotrophic bacteria. Microbiol Rev 60, 439-471.

Jahng, D. \& Wood, T. K. (1994). Trichloroethylene and chloroform degradation by a recombinant pseudomonad expressing soluble methane monooxygenase from Methylosinus trichosporium OB3b. Appl Environ Microbiol 60, 2473-2482.

Jahng, D., Kim, C. S., Hanson, R. S. \& Wood, T. K. (1996). Optimisation of trichloroethylene degradation using soluble 
methane monooxygenase of Methylosinus trichosporium OB3b expressed in recombinant bacteria. Biotechnol Bioeng 51, 349-359.

Keen, N. T., Tamaki, S., Kobayashi, D. \& Trollinger, D. (1988). Improved broad-host-range plasmids for DNA cloning in Gramnegative bacteria. Gene 70, 191-197.

Knauf, V. C. \& Nester, E. W. (1982). Wide host range cloning vectors: a cosmid clone bank of Agrobacterium Ti plasmids. Plasmid 8, 45-54.

Laemmli, U. K. (1970). Cleavage of structural proteins during the assembly of the head of the bacteriophage T4. Nature 227, $680-685$.

Lipscomb, J. D. (1994). Biochemistry of the soluble methane monooxygenase. Annu Rev Microbiol 48, 371-399.

Lloyd, J. S., Bhambra, A., Dalton, H. \& Murrell, J. C. (1997). Inactivation of the regulatory protein $\mathrm{B}$ of soluble methane monooxygenase from Methylococcus capsulatus (Bath) by proteolysis can be overcome by a Gly to Gln modification. Eur J Biochem 248, 72-79.

Low, B. (1968). Formation of merodiploids in matings with a class of $\mathrm{Rec}^{-}$recipient strains of Escherichia coli K12. Proc Natl Acad Sci USA 60, 160-167.

Lund, J., Woodland, M. P. \& Dalton, H. (1985). Electron transfer reactions in the soluble methane monooxygenase of Metbylococcus capsulatus (Bath). Eur J Biochem 147, 297-305.

Martin, H. (1994). Molecular genetics of methane oxidation in Methylosinus trichosporium OB3b. PhD thesis, University of Warwick.

Martin, H. \& Murrell, J. C. (1995). Methane monooxygenase mutants of Methylosinus trichosporium constructed by markerexchange mutagenesis. FEMS Microbiol Lett 127, 243-248.

Murrell, J. C. (1994). Molecular genetics of methane oxidation. Biodegradation 5, 145-159.

Nguyen, H. H. T., Elliott, S. J., Yip, J. H. K. \& Chan, S. I. (1998). The particulate methane monooxygenase from Methylococcus capsulatus (Bath) is a novel copper-containing three-subunit enzyme - isolation and characterization. J Biol Chem 273, 7957-7966.

Nielsen, A. K., Gerdes, K., Degn, H. \& Murrell, J. C. (1996). Regulation of bacterial methane oxidation: transcription of the soluble methane monooxygenase operon of Metbylococcus capsulatus (Bath) is repressed by copper ions. Microbiology 142, 1289-1296.

Nielsen, A. K., Gerdes, K. \& Murrell, J. C. (1997). Copperdependent reciprocal transcriptional regulation of methane monooxygenase genes in Methylococcus capsulatus and Methylosinus trichosporium. Mol Microbiol 25, 399-409.

Oldenhuis, R. \& Janssen, D. B. (1993). Degradation of trichloroethylene by methanotrophic bacteria. In Microbial Growth on $C_{1}$ Compounds, pp. 121-133. Edited by J. C. Murrell \& D. P. Kelly. Andover: Intercept Press.

Oldenhuis, R., Vink, R. L. J. M., Janssen, D. B. \& Witholt, B. (1989). Degradation of chlorinated aliphatic hydrocarbons by Metbylosinus trichosporium OB3b expressing soluble methane monooxygenase. Appl Environ Microbiol 55, 2819-2826.

Park, S., Hanna, L., Taylor, R. T. \& Droege, M. W. (1991). Batch cultivation of Methylosinus trichosporium OB3b. 1. Production of soluble methane monooxygenase. Biotechnol Bioeng 38, 423-433.

Pilkington, S. J. (1986). The soluble methane monooxygenase and ammonia oxidation in the obligate methanotroph Methylosinus trichosporium $\mathrm{OB} 3 b$. PhD thesis, University of Warwick.

Pilkington, S.J. \& Dalton, H. (1990). Soluble methane monooxygenase from Metbylococcus capsulatus (Bath). Methods Enzymol 188, 181-190.

Prentki, P. \& Krisch, H. M. (1984). In vitro insertional mutagenesis with a selectable DNA fragment. Gene 29, 303-313.

Rosenzweig, A. C., Frederick, C. A., Lippard, S. J. \& Nordlund, P. (1993). Crystal structure of a bacterial non-haem iron hydroxylase that catalyses the biological oxidation of methane. Nature $\mathbf{3 6 6}$, 537-543.

Rosenzweig, A. C., Nordlund, P., Takahara, P. M., Frederick, C. A. \& Lippard, S. J. (1995). Geometry of the soluble methane monooxygenase catalytic diiron centre in two oxidation states. Chem Biol 2, 409-418.

Rosenzweig, A. C., Brandstetter, H., Whittington, D. A., Nordlund, P., Lippard, S. J. \& Frederick, C. A. (1997). Crystal structures of the methane monooxygenase hydroxylase from Methylococcus capsulatus (Bath): implications for substrate gating and component interactions. Proteins Struc Funct Genet 29, 141-152.

Sambrook, J., Fritsch, E. F. \& Maniatis, T. (1989). Molecular Cloning: a Laboratory Manual. 2nd edn. Cold Spring Harbor, NY: Cold Spring Harbor Laboratory.

Saunders, S. E. \& Burke, J. F. (1990). Rapid isolation of miniprep DNA for double strand sequencing. Nucleic Acids Res 18, 4948-4949.

Simon, R., Priefer, U. \& Pühler, A. (1983). A broad host range mobilisation system for in vivo genetic engineering: transposon mutagenesis in Gram-negative bacteria. Biotechnology 1, 784 791.

Stanley, S. H., Prior, S. D., Leak, D. J. \& Dalton, H. (1983). Copper stress underlies the fundamental change in intracellular location of methane monooxygenase in methane-oxidising organisms: studies in batch and continuous cultures. Biotechnol Lett $\mathbf{5}$, $487-492$.

Stirling, D. I. \& Dalton, H. (1979). Properties of the methane monooxygenase from extracts of Methylosinus trichosporium OB3b and evidence for its similarity to the enzyme from Methylococcus capsulatus (Bath). Eur J Biochem 96, 205-212.

Toukdarian, A. E. \& Lidstrom, M. E. (1984). Molecular construction and characterisation of nif mutants of the obligate methanotroph Methylosinus sp. strain 6. J Bacteriol 157, 979-983.

Tsien, H.-C., Brusseau, G. A., Hanson, R. S. \& Wackett, L. P. (1989). Biodegradation of trichloroethylene by Metbylosinus trichosporium OB3b. Appl Environ Microbiol 55, 3155-3161.

West, C. A., Salmond, G. P. C., Dalton, H. \& Murrell, J. C. (1992). Functional expression in Escherichia coli of proteins $\mathrm{B}$ and $\mathrm{C}$ from soluble methane monooxygenase of Methylococcus capsulatus (Bath). J Gen Microbiol 138, 1301-1307.

Woodland, M. P. \& Dalton, H. (1989). Purification and characterisation of Component A of the methane monooxygenase from Methylococcus capsulatus (Bath). J Biol Chem 259, 53-59.

Zahn, J. A. \& DiSpirito, A. A. (1996). Membrane associated methane monooxygenase from Methylococcus capsulatus (Bath). $J$ Bacteriol 178, 1018-1029.

Received 19 June 1998; revised 22 September 1998; accepted 28 October 1998. 